\section{В.Д.Мішалов ${ }^{1}$ О.В.Михайленко ${ }^{2}$ \\ ${ }^{1}$ Національна медична ака- демія післядипломної освіти імені П.Л. Шупика \\ ${ }^{2}$ Київське міське клінічне бюро судово-медичної екс- пертизи \\ Київ}

Ключові слова: мікрорентгенівський флуоресцентний спсктральний с.тсмснтний аналіз, вогнепальні ушкодження.

Надіïuла: 13.07.2016

Прийнята: 20.08.2016
DOI: https://doi.org/10.26641/1997-9665.2016.3.373-376

УДК 340.64:343.97:616-035.8

\section{НОВІ МОЖЛИВОСТІ ЛАБОРАТОРНОЇ ДІАГНОСТИКИ ПРОДУКТІВ ПОСТРІЛУ ІІЛЯХОМ ПРОВЕДЕННЯ МІКРОРЕНТ- ГЕНОФЛУОРЕСЦЕНТНОГО СПЕКТРА- ЛЬНОГО ЕЛЕМЕНТНОГО АНАЛІЗУ}

Реферат. IІа основі використання спектрометру «M4 TORNADO» виявлені нові можтивості лабораторної діагностики продуктів пострілу шляхом проведення мікроренттенівського флуоресцентного спектрального елементного аналізу. Його переваги з аналогічними методами полягають у можливості створення карт топографії як загальннх карт елементів, так і окремих елементів та їх комӧінацій. Наявність 10× та 100× кратних об’єктивів надає можливість проведення прищільного «мікроскопічного» дослідження частини обраної ділянки за топографією елементів на карті.

Morphologia. - 2016. - T. 10, № 3. - C. 373-376.

(с) В.Д.Міпалов, О.В.Михайленко, 2016

\begin{abstract}
Mishalov V.D., Michailenko O.V. New opportunities in laboratory diagnostics of shot products by their x-ray fluorescence spectral element analysis.

ABSTRACT. Background. Optical Spectroscopic techniques widely used in practice despite the high sensitivity and wide range of studied chemical elements have the drawbacks, such as sample preparation, which is possible only in case of destruction of the investigated object. Non-destructive method to investigate the elemental composition of metal layers and other products of the shot is X-ray fluorescence spectral analysis, but the knowledge about the possibilities of modern equipment is incomplete. Objective. Identify chemical elements in damage simulator clothes at experimental shots from firearms through X-ray fluorescence spectral element analysis using a spectrometer «M4 TORNADO» manufactured by Bruker. Methods. The object of study was damaged clothe (patches of leather of jacket). Micro X-ray fluorescence spectral element analysis with a spectrometer «M4 TORNADO» manufactured by Bruker (Germany) was applied. Results. Use of technical capabilities and software spectrometer «M4 TORNADO» provides new opportunities for laboratory diagnosis of various chemical elements in the tissues of biological and non-biological origin, including shot products through micro X-ray fluorescence spectral element analysis. Its advantages over similar methods are the possibility of mapping the topography as common maps of elements, maps for individual elements and their combinations. Analyzing the distribution pattern of elements on maps researcher has an opportunity to interpret the character of layers and background concentrations of the elements by their intensity. Conclusion. Tested equipment and program software opens new opportunities for laboratory diagnostics of shot products by their X-ray fluorescence spectral element analysis.
\end{abstract}

Key words: micro X-ray fluorescence spectral element analysis, gunshot injuries.

Citation:

Mishalov VD, Michailenko OV. [New opportunities in laboratory diagnostics of shot products by their x-ray fluorescence spectral element analysis]. Morphologia. 2016;10(3):373-6. Ukrainian.

\section{Ветуп}

Як свідчать О. В. Филипчук, О. М. Гуров [1], у ХХ столітті були розроблені методи дослідження не тільки металів від куль, гільз, ствола зброї, що утворюються під час пострі.лу 3 вогнепальної зборої, але і компонентів згоряння пороху, тобто, факторів, що супроводжують постріл (продуктів пострілу)

Оптичні спектральні методи (емісійний спектрографічний, полум'яна емісійна фотометрія, інфрачервона спектрометрія, іскрова масспектрометрія, атомно-абсорбційний аналіз, нейтронно-активаційний аналіз і ін.), які широко використовуються на практиці, незважаючи на високу чутливість і великий діапазон досліджуваних хімічних елементів, для судової медицини мають істотний недолік такий, як підготовка проби, що можливо лише за умови руйнування об'єкту дослідження.

Неруйнівним методом дослідження елементного складу нашарувань металів та інших продуктів пострілу є рентгенівський флуоресцентний спектральний аналіз (далі - РФСА). Вказаний метод дослідження полягає в опроміненні об'єкту дослідження пучком рентгенівсыкого випромінювання і реєстрації вторинного випро- 
мінювання в рентгенівському діапазоні, при чому спектральний склад вторинного випромінювання відображає елементний склад об́ єкта.

У випадках вогнепальної травми можливості РФСА дозволяють проводити діагностику ушкодження, ідентифікувати мікрочастинки 3 ранових каналів, визначати вид снаряду і мікроелементний склад продуктів пострілу.

Позитивні сторони і ефективність цього методу була викладена в роботах О. П. Колоса [2, 3], М. А. Федоренка [4] і інш. Автори вказують, що метод РФСА при практично такій же чут.лвості має наступні переваги: він зменшує трудоємкість процесу, забезпечує більшу швидкість одержання результатів, повне збереження об'єкта і зони дослідження, можливість проведення повторних досліджень даним або будьяким іншим методом, широкий діапазон досліджуваних елементів (більше 70), наочні і достовірні результати, допустимість дослідження об'єктів у будь-якому агрегатному стані (крім газу), відсутність необхідності попередньої підготовки або обробки об'єктів, наявність програмного забезпечення, що дозво.яє проводити комп'ютерну обробку й архівування отриманих результатів.

Навсдсні вище дослідження О. П. Колоса [2, 3] і М. А. Федоренка [4] стосовно особливостей продуктів пострі.лу виконувались 7-8 років тому назад на приладі "ElvaX" (м. Київ, Україна). Протягом останніх років технологічні можливості РСФА суттєво зросли, хоча вітчизняних робіт, що присвячені таким дослідженням - недостатНь०.

Метою дослідження було виявлення хімічних елементів в ушкодженнях імітаторів одягу при експериментальних пострі.лах 3 вогнепальної збррої шляхом проведення мікрорентгенівського флуоресцентного спектрального елементного аналізу 3 використаннямспектрометру «М4 TORNADO» виробництва компанії Bruker (Hiмeччина).

\section{Матеріали та метод досліджешня}

Об'єктами дослідження були пошкодження одягу (клапті шкіри, з якої виготовлена куртка), а саме - пояски обтирання, шо утворились при пострілах із пістолета патронами калібру 7,65 мм 3 відстані 5 м, а саме: 30 зразків, 3 яких 15 при влучанні кулі під прямим кутом в плошину мішені та 15 зразків із архівного матеріалу бюро експертизи, які проводилися у відділенні судовомедичної криміналістики. Виявлення хімічних елементів, які входять до складу факторів, шо супроводжують постріл, проводилося шляхом рентгенівського флуоресцентного спектрального аналізу 3 використанням спектрометра «M4 TORNADO» компанії Bruker (Німеччина) iз застосуванням стандартних аналітичних методик. Досліджувані об'єкти опромінювались пучком рентгенівського випромінювання, сформований мікрокапілярною рентгенівською оптикою. В атомах об'єкту проходило збудження 3 випусканням унікального для кожного елементу флуоресцентного рентгенівського випромінювання, інтенсивність якого реєструвалася детектором. Джерелом рентгенівського випромінювання в спектрометрі була мікрофокусна рентгенівська трубка, яка працювала при анодній напрузі $50 \mathrm{keV}$ та анодному струмі в $600 \mu \mathrm{A}$. Об' єкти дослідження помішали в робочу камеру спектрометру, при тиску у 20 mbar, який створювався вакуумною помпою.

В роботі були використані стандартні методи варіаційної статистики. Розрахунок похиб̆ки та відхилення проводилося програмним забезпеченням, яке входить до складу софту самого приладу.

Результати та їх обговорення

Встановлено, що при пострілі 3 каналу зброї виносяться частинки матеріалу: ствола зброї, металеві частини патрону (куля, гільза та капсуль), а також продукти горіння порохових зарядів, тобто, були виявлені хімічні елементи (метали), найменування і походження яких вказано в таблиці №1.

Таблиця 1

Найменування і джерела походження елементів в продуктах пострілу

\begin{tabular}{lc}
\hline Джсрсло походжсння & Елемент \\
\hline Ствол & $\mathrm{Fe}$ \\
Гільза & $\mathrm{Fe}, \mathrm{Cu}, \mathrm{Zn}$ \\
Капсюль (оболонка, ковпачок, прокладка, кружок) & \\
Куля & $\mathrm{Ba}, \mathrm{Fe}, \mathrm{Cu}, \mathrm{Zn}, \mathrm{Sb}, \mathrm{Sn}, \mathrm{Pb}$ \\
- безоболонкова & $\mathrm{Pb}$ \\
- оболонкова: & \\
оболонка & $\mathrm{Fe}, \mathrm{Cu}, \mathrm{Zn}, \mathrm{Ni}$ \\
осердя & $\mathrm{Fe}, \mathrm{Cu}, \mathrm{Zn}, \mathrm{W}, \mathrm{Al}, \mathrm{Pb}$ \\
\hline
\end{tabular}

Піс.ля визначення спектру хімічних елементів на досліджуваній ділянки було проведене картування виявлсних елементів. Для цього, на досліджуваних об’єктах була задана площа ска- 
нування, яка складалася із 800 крапок по горизонталі та 570 крапок по вертикалі. Під час опромінення об'єкт дослідження в камері перемішувався по точках на рухомому в трьох площинах столику, шо і давало можливість отримання карти розподілу елементів на площині сканування.

В результаті було отримано карти розподі.ту хімічних елементів на обраній плошині сканування клаптів шкіри в ділянці пошкодження (рис. 1-7)

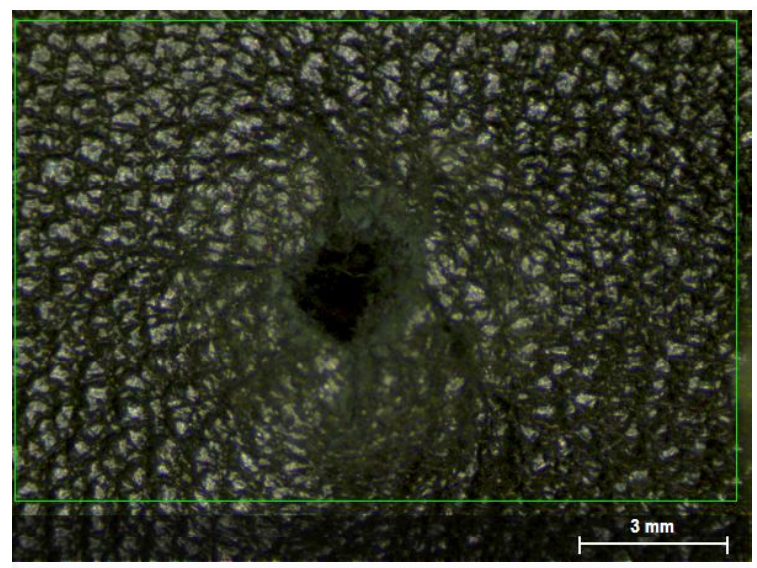

Рис. 1. Зовнішній вигляд пошкодження на шкірі та обрана для сканування ділянка навколо вхідного вогнепального кульового пошкодження

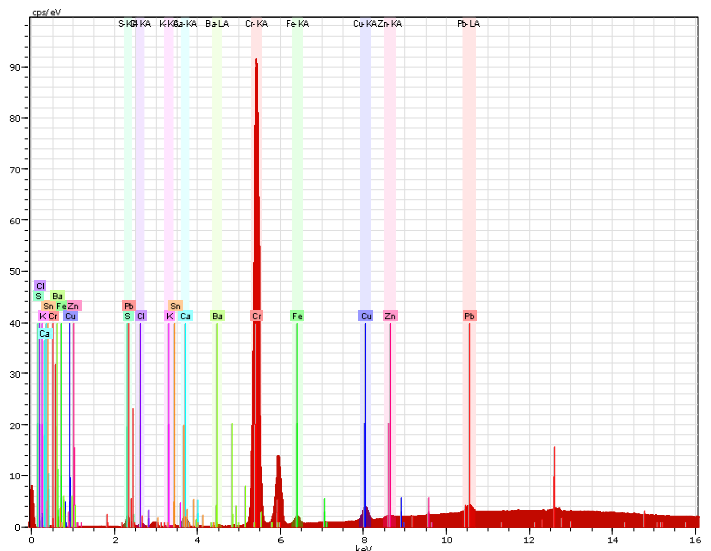

Рис. 2. Гістограма піків ліній виявлених елементів.

Оскільки дослідження проводиться на високому апаратному рівні, має широкий діапазон вибору елементів (від $\mathrm{Na}$ до $\mathrm{U}$ ), не має розхідних матеріалів та не залежить від якості реактивів, i дотримання умов проведення реакщії, як це традиційно прийнято при застосуванні контактнодифузійного методу, то на себе звернув увагу i сам результат проведеного картування хімічних елементів, який мав чітку топографію та морфологію. Також оцінку характеру нашарувань в ділянці пошкодження розширює можливість створення карт топографії окремих елементів, їх комбінації та загальних карт обраних елементів.
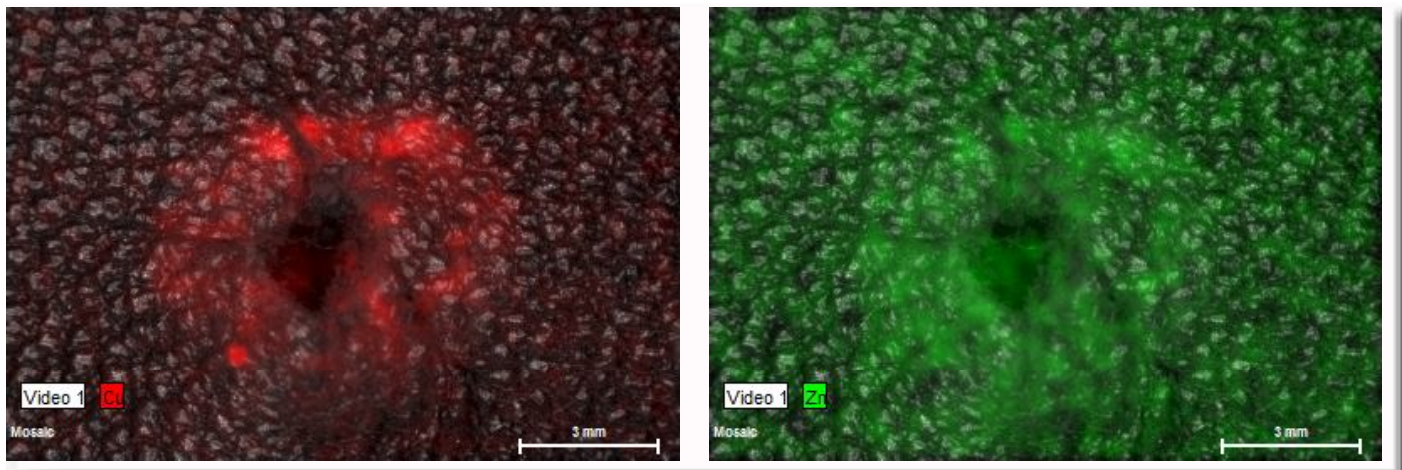

Рис. 3-4. Карти розподілу міді (Cu-KA)та цинку ( $\mathrm{nn-KA)} \mathrm{на} \mathrm{обраній} \mathrm{для} \mathrm{сканування} \mathrm{ділянці} \mathrm{навколо} \mathrm{вхідного} \mathrm{вогне-}$ пального кульового пошкодження.
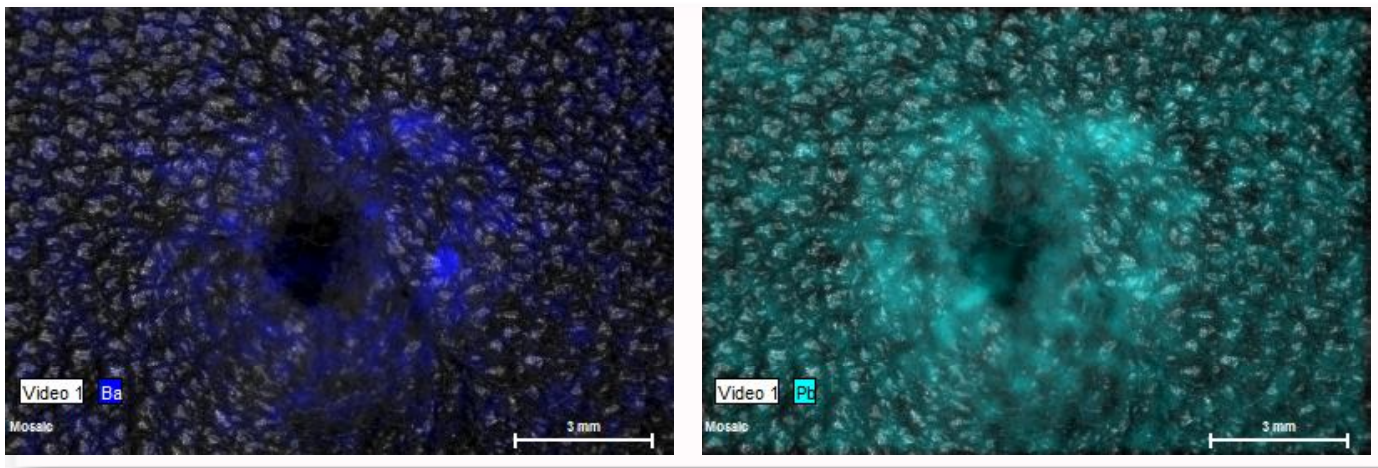

Рис. 5-6. Карти розподілу барію (Ba-LA) та свинцю (Pb-LA) на обраній для сканування ділянці навколо вхідного вогнепального кульового пошкодження. 


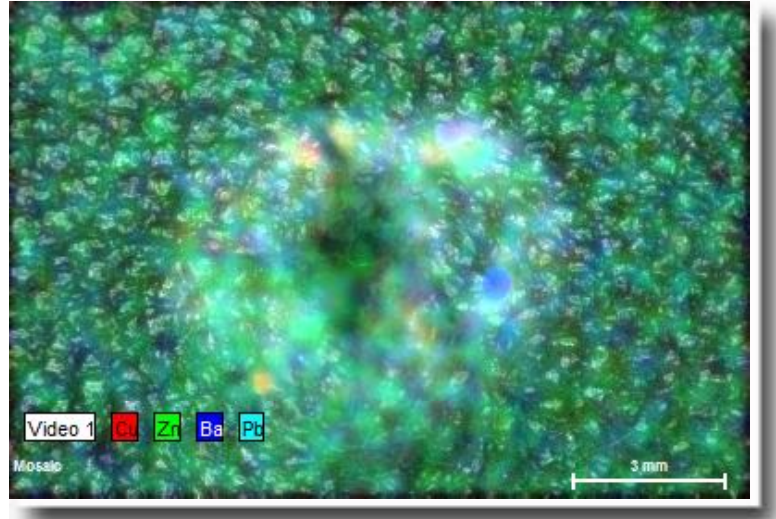

Рис. 7. Загальна карта розподілу міді, цинку, барію та свинцю на обраній для сканування ділянці навколо вхідного вогнепального кульового пошкодження.

При цьому, топографія та морфологія розподілу наявних в ді.лянці пошкодження хімічних елементів, без урахування морфології самих пошкоджснь, вказували на їх вогнспальне походження.

\section{Висновки}

1. Отже, використання технічних можливостей та програмного забезпечення спектромстру «M4 TORNADO» забезпечує нові можливості лабораторної діагностики різних хімічних елементів у складі тканин біологічного і небіологічного походження, зокрема продуктів пострі.уу, шляхом проведення мікрорентгенівського флуорссцентного спектрального елементного аналізу.

2. Його переваги 3 аналогічними методами полягають у можливості створення карт топографії, як загальних карт елементів, так і окремих елементів та їх комобінацій.

3. Наявність $10 \times$ та $100 \times$ кратних об єктивів надає можливість проведення прицільного «мікроскопічного» дослідження частини обраної ділянки за топографією елементів на карті.

4. При аналізі характеру розподілу елементів на отриманих картах дослідник має можливість за інтенсивністю розцінити характер нашарувань та фонові значення концентрації елементів, шо створює передумови для відмови у проведенні дослідження контрольного зразка (зони мішені без пошкодження).

Перспективи подалыших досліджень полягають у поглибленій ідентифікації мікроелементного складу продуктів пострі.лу 3 біологічних об'єктів та об̆'єктів не біологічного походжсння.

\section{Літературні джере.ла \\ References}

1. Fylypchuk OV, Gurov OM. [Forensic criminalistics: a textbook]. Kharkiv: Disa Plus; 2013: 640 p. Ukrainian.

2. Kolos AP. [Forensic characteristics of the damage of various kinds of fabrics (materials) clothing fired with cartridges "AL-9P" equipped with elastic bullets]. Problemy viiskovoi okhorony zdorovya. 2009 ; 25 : 259-68. Ukrainian.

3. Kolos OP. [Possibilities of medicolegal identification of the fact of using cartridges 'PND-9P',
'Osa' and 'AL-9R' at drawing damage by elastic bullets]. Collection of scientific works of staff members of NMAPE named after P.L.Shupyk. 2009:18(2): 250-9. Ukrainian.

4. Fedorenko MA. [Morphological features of gunshot injuries caused by cartridge $9 \times 18 \mathrm{~mm}$ equipped with anti-ricochet bullets]. Collection of scientific works of staff members of NMAPE named after P.L. Shupyk 2009;18(3): 694-8. Ukrainian.

Мишалов В.Д., Михайленко А.В. Новые возможности лабораторной диагностики продуктов выстрела путем проведения микрорегенф.луорисцентного спектрального элементного анализа.

Резюме. На основе использования спектрометра «M4 TORNADO» обнаружены новые возможности лабораторной диагностики продуктов выстрела путем проведения микрорентгеновского флуоресцентного спектрального элсмснтного анализа. Его прсимущсства с аналогичными мстодами заключаются в возможности создания карт топографии, как обших карт элементов, так и отдельных элементов и их комбинаций. Наличие $10 \times$ и $100 \times$ кратных объъективов предостав.ляст возможность провсдсния прицельного «микроскопичсского» исслсдования части выбранного участка за топографией элементов на карте.

Ключевые слова: микрорентгеновский флуоресцентный спектральный элементный анализ, огнестрсльныс поврсждсния. 